\title{
Effects of Arg-Gly-Asp Sequence Peptide and Hyperosmolarity on the Permeability of Interstitial Matrix and Fenestrated Endothelium in Joints
}

\author{
A. POLI, ${ }^{*}$ R. M. MASON, ${ }^{\dagger}$ AND J. R. LEVICK* \\ *Department of Physiology, St George's Hospital Medical School, London, UK; and †Division of \\ Biomedical Sciences, Faculty of Medicine, Imperial College, London, UK
}

\begin{abstract}
Objectives: The aims were to assess the contribution of arg-gly-asp (RGD) mediated cell integrinmatrix bonds to interstitial hydraulic resistance and to fenestrated endothelial permeability in joints. Joint fluid is generated by filtration from fenestrated capillaries and drains through a fibronectinrich synovial intercellular matrix. The role of parenchymal cell-matrix bonding in determining tissue hydraulic resistance is unknown.
\end{abstract}

Methods: The knee cavity of anesthetized rabbits was infused with saline or the competitive hexapeptide blocker GRGDTP, with or without added osmotic stress (600 mosm saline). Intra-articular pressure $P_{\mathrm{j}}$, net trans-synovial drainage rate $\dot{Q}_{\mathrm{s}}$, and the permeation of Evans blue-labeled albumin (EVA) from plasma into the joint cavity were measured.

Results: GRGDTP increased the hydraulic conductance of the synovial drainage pathway, $\mathrm{d} \dot{Q}_{\mathrm{s}} / d P_{\mathrm{j}}$, by $71 \%(p=.02$, paired $t$ test, $n=6$ animals). Synovial plasma EVA clearance (control $7.1 \pm 0.8 \mu \mathrm{L}$ $\mathrm{h}^{-1}$, mean \pm SEM, $\left.n=15\right)$ was unaffected by GRGDTP $\left(7.0 \pm 2.3 \mu \mathrm{L} \mathrm{h}^{-1}, n=6\right)$ or hyperosmolarity $\left(4.9 \pm 1.5 \mu \mathrm{L} \mathrm{h}^{-1}, n=8\right)$ but was increased by GRGDTP and hyperosmolarity together $(15.9 \pm$ $\left.4.8 \mu \mathrm{L} \mathrm{h}^{-1}, n=5\right)(p=.01$, ANOVA $)$. Changes in $d P_{\mathrm{j}} / d t$ evoked by GRGDTP plus hyperosmolarity, but neither alone, demonstrated increased microvascular filtration into the joint cavity $(p<.001$, ANOVA), as did changes in fluid absorption from the infusion system at fixed $P_{\mathrm{j}}$.

Conclusions: RGD-mediated bonds between the parenchymal cells and interstitial polymers reduce the interstitial hydraulic conductance by $42 \%$. This helps to retain the lubricating fluid inside a joint cavity. RGD-mediated bonds also support the macromolecular barrier function of fenestrated endothelium, but in vivo this is evident only in stressed endothelium (cf. in vitro).

Microcirculation (2004) 11, 463-476. doi:10.1080/10739680490476024

KEY WORDS: fenestrated endothelium, integrins, interstitium, joints, osmolarity, permeability, RGD, synovium

\section{INTRODUCTION}

Synovium, the sheet of tissue surrounding a joint cavity, is responsible for both the formation and the drainage of the lubricating fluid in the cavity. Its accessibility makes it a useful model for studying interstitial permeability, as well as being functionally important. Synovium is composed of a discontinuous layer of fibroblast-related synoviocytes and

The research was funded by Wellcome grant 056983/Z/99 and European Community TMR grant ERBFMRXCT980219.

Address correspondence to J. R. Levick, Department of Physiology, St George's Hospital Medical School, London, SW17 ORE, UK. E-mail: tvttfyheot63@hotmail.com

Received 21 November 2003; accepted 9 February 2004. macrophages with broad interstitial spaces and a network of fenestrated capillaries just below the surface. In extended joints the pressure in the cavity is low and the capillaries slowly filter fluid into the cavity. Flexion raises the intraarticular pressure and drives fluid out of the cavity through the synovial interstitial matrix into the periarticular lymphatic system. maintaining volume homeostasis. The interstitial hydraulic resistance is thus a crucially important coupling coefficient in joint fluid turnover, as is also the case in many other tissues.

Interstitial hydraulic resistance is the result of hydraulic drag by the interstitial matrix biopolymers (49). In synovium these include fibronectin, vitronectin, laminin, tenascin, entactin, fibromodulin, heparan, and chondroitin sulfate proteoglycans, 
hyaluronan, and collagen types I, III, IV, V, and VI $(27,33)$. To generate hydraulic drag, however, the biopolymers must be anchored, and the role of anchorage has received relatively little investigation. Anchorage could arise in principle from extracellular polymer-polymer interactions, as in cartilage, and/or from cellular-extracellular linkages. The contribution of the latter to interstitial hydraulic resistance has never, to our knowledge, been studied. Synovium may, in principle, utilize both types of anchorage. For example, fibronectin is abundant in synovium (29) and binds to extracellular fibrin, collagen types I, III, $\mathrm{V}$, and VI $(15,55)$ and heparan sulfate proteoglycan $(54)$, as well as to the synovial lining cell integrins $\alpha_{5} \beta_{1}$ and $\alpha_{\mathrm{V}} \beta_{1}(16,42)$.

The integrins are a family of $>20$ transmembrane $\alpha-\beta$ heterodimers that are tethered to the cytoskeleton via talin, vinculin, and $\alpha$-actinin at focal adhesions. Both the synovial parenchymal cells and the endothelium express the integrins $\alpha_{5} \beta_{1}$ (binds fibronectin) $(1,9,16,30) ; \alpha_{\mathrm{V}} \beta_{3}$ (binds vitronectin, fibronectin, tenascin, fibrinogen) $(43,52) ; \alpha_{6} \beta_{1}$ (binds laminin) (16.36), and $\alpha_{1} \beta_{1}$ (binds collagen and laminin) (35). Synovial parenchymal cells also express $\alpha_{V} \beta_{1}$ (binds vitronectin, fibronectin) $(15,33)$. Integrins not only anchor matrix polymers but also mediate outside-to-in signaling via integrin-linked kinases, which can transduce matrix stress into intracellular signaling cascades $(12,31,45,48,51)$. Integrins also mediate inside-to-out effects, such as the regulation of interstitial fluid pressure by fibroblasts through $\alpha_{2} \beta_{1}$-collagen bonds in rat skin and tracheal mucosa $(2,41)$ and endothelial barrier regulation (see below).

A specific arginine-glycine-aspartate (RGD) consensus sequence in the extracellular biopolymer ligand mediates around half the known integrinligand interactions, including $\alpha_{5} \beta_{1}$-fibronectin and $\alpha_{V} \beta_{1}$-vitronectin $(15,31,46)$. The assembly of soluble fibronectin into matrix fibrils involves both $\alpha_{5} \beta_{1}$ RGD and $\alpha_{\mathrm{V}} \beta_{3}$-RGD interactions (56). The RGD consensus sequence is exposed in fibronectin, vitronectin, fibrinogen, von Willebrand factor, laminin, entactin, tenascin, and some forms of collagen. The RGD sequence is recognized by the integrins $\alpha_{5} \beta_{1}$. $\alpha_{8} \beta_{1}, \alpha_{V} \beta_{1}, \alpha_{V} \beta_{3 / 5 / 6 / 8}$, and in some cases $\alpha_{2} \beta_{1}$ (46).

When cells bound to glycoproteins are exposed to a suitably flanked, synthetic RGD-sequence oligopeptide, such as GRGDTP (Gly-Arg-Gly-Asp-Thr-Pro) or GRGDSP ( $\mathrm{S}$, serine), the competition between the oligopeptide and endogenous glycoprotein for $\alpha_{5} \beta_{1}$ and $\alpha_{V} \beta_{1}$ binding sites leads to cell detachment $(11,13,46)$. GRGDTP also inhibits cell attachment to perlecan, fibrinogen, and von Willebrand factor $(4,30)$ and in some cell lines $\alpha_{1} \beta_{1} / \alpha_{2} \beta_{1}$-collagen binding, but not laminin or collagen type IV binding $(11,46)$. These effects are quite rapid. RGD-sequence peptide causes cell detachment and rounding in vitro within $2 \mathrm{~h}$ (5). In endothelium in situ, RGD evokes changes that are detectable within $5 \mathrm{~min}$, persist up to $3 \mathrm{~h}$, are maximal at $\geq 10^{-4} \mathrm{M}$ peptide, and are reversed by washout (57). The above observations show that integrin-RGD links are dynamic and accessible to competitive block by exogenous RGDsequence peptide.

Many studies in vitro have shown that RGD-integrin interactions support the barrier function of continuous endothelium from macrovessels grown on an artificial base such as fibronectin (3). The treatment of such monolayers with RGD-sequence peptide or $\alpha_{5} \beta_{1}$ antibody increases the macromolecular permeability $(7,21)$, raises the hydraulic conductance 3 -fold, reduces endothelial adhesion and causes intercellular gap formation (40). The integrin expression and permeability of macrovessel endothelium cultured in vitro on a synthetic substrate is not necessarily a safe guide, however, to the properties of intact microvessels in vivo. Much less is known about the functional importance of RGD-mediated bonds in intact microvessels, and nothing is known in relation to fenestrated endothelium. In isolated porcine coronary venules, RGD-sequence peptide increased the albumin permeability by up to 4.5 -fold within minutes (57). By contrast, in the only studies on microvessels in situ, namely frog mesenteric venules, neither GRGDTP alone nor hyperosmolar saline alone affected the endothelial hydraulic conductance $(17,18)$. When 10-min exposure to GRGDTP was supplemented by osmotic stress, however, the endothelial conductance increased by $\sim 27 \%$. Thus, in the continuous endothelium of amphibia in vivo it was necessary to increase the stress on weakened/residual integrin-matrix bonds to reveal RGD bond functionality. In view of the partially conflicting literature, there is a need to investigate further the role of RGD in intact microvessels in vivo. Moreover, the role of RGD in fenestrated endothelium, as opposed to continuous endothelium, has never previously been investigated.

The present study therefore tests the hypotheses that (1) RGD-mediated bonds between interstitial matrix and parenchymal cell integrins contribute to interstitial hydraulic resistance; and (2) fenestrated 
endothelial barrier function in vivo depends partly on RGD-mediated bonds. These hypotheses were tested by infusing rabbit knee joints with GRGDTP in isotonic or hyperosmotic saline and measuring their effects on 3 parameters: plasma-to-joint protein permeation (a measure of endothelial barrier function), changes in joint fluid pressure with time (an index of capillary filtration rate), and the trans-synovial drainage rate versus pressure relation (a measure of synovial interstitial matrix conductance). Synthetic RGD rather than a specific anti-integrin or antimatrix antibody was chosen as the blocking agent for several reasons, including the "broad-spectrum" blockade of multiple types of RGD-dependent bonds by RGD (cf. limited, selective block by specific antibodies), the extremely high cost of sufficient antibody for rabbits in vivo, and a commercial lack of specifically anti-rabbit antibodies.

\section{METHODS}

\section{Overview}

The study used an established rabbit knee model. After an iv injection of Evans blue-labeled albumin (EVA) into the plasma compartment, the joint cavity was cannulated to record intraarticular pressure $\left(\dot{P}_{\mathrm{j}}\right)$. A small bolus of isotonic/hypertonic saline \pm GRGDTP was injected intraarticularly and the $P_{\mathrm{i}}$ response was recorded for $30 \mathrm{~min}$. A second cannula was then introduced and connected to a raised fluid reservoir and in-line drop counter. The reservoir height controlled $P_{\mathrm{j}}$, and this was increased every 15 min to chart the relation between $P_{\mathrm{j}}$ and net transsynovial flow $\dot{Q}_{\mathrm{S}}$. Intraarticular fluid was aspirated every 15 min to quantify EVA permeation across the blood-joint barrier. The key measured parameters were thus $d P_{\mathrm{j}} / d t$, which reflects the imbalance between interstitial drainage from the cavity and capillary filtration into it: $\mathrm{Cl}_{\mathrm{EVA}}$, the clearance of Evans blue-albumin from synovial plasma into joint cavity; and $d \dot{Q}_{\mathrm{S}} / d P_{\mathrm{j}}$, the hydraulic conductance of the synovial lining. The experiment was usually repeated on the contralateral joint with an appropriate control solution.

\section{Experimental Preparation: Determination of $d P_{\mathrm{j}} / d t$ and $d \dot{Q}_{\mathrm{S}} / d P_{\mathrm{j}}$}

New Zealand white rabbits of 2.5-3 kg were anesthetized with $30 \mathrm{mg} \mathrm{kg}^{-1}$ sodium pentobarbitone plus $500 \mathrm{mg} \mathrm{kg}^{-1}$ urethane iv and tracheostomized. Anesthesia was maintained at sufficient depth to abolish the corneal blink reflex using intravenous $15 \mathrm{mg}$ sodium pentobarbitone plus $250 \mathrm{mg}$ urethane every $30 \mathrm{~min}$. Procedures conformed to United Kingdom animal legislation and the animals were killed humanely by an overdose of iv sodium pentobarbitone at the end of the experiment.

The intraarticular infusion system, pressure and flow transducers, and chart recorder were as described in (6) and (38). Initially a single cannula was inserted into the joint cavity to deliver a bolus of 200 to $300-\mu \mathrm{L}$ test solution. The subsequent decay/rise in $P_{\mathrm{j}}$ was followed for $30 \mathrm{~min}$. The pressure decay provides information about the balance between microvascular filtration into the joint cavity and transsynovial drainage out of it through the parallel interstitial pathway (37). The reason is as follows. In a closed joint the fluid pressure $P_{\mathrm{j}}$ at constant joint angle depends on intraarticular fluid volume and elastance (19). Changes in net trans-synovial flow alter the intraarticular volume and therefore $P_{\mathrm{j}}$. The net trans-synovial flow in vivo is the difference between the capillary filtration into the cavity and the spatially separate trans-synovial drainage out of it (23). A similar study was repeated post mortem, because integrin-matrix influences on interstitial fluid pressure are best demonstrated after capillary perfusion has ceased (41).

After 30 min the intraarticular fluid was aspirated for EVA analysis (see below) and a second intraarticular cannula was inserted and connected to an infusion reservoir. The height of the reservoir clamped $P_{\mathrm{j}}$ at any desired level. Flow from the infusion reservoir into the joint cavity, $\dot{Q}_{\text {in }}$, was recorded by a photoelectric drop counter. Due to the very high cost of synthetic hexapeptide, only the terminal $10 \mathrm{~mL}$ of the infusion system was filled with the test solution. An inverted-U air gap separated the test solution from drop counter fluid, namely $0.1 \% \mathrm{v} / \mathrm{v}$ chlorhexidine (Hibitane, ICI, Macclesfield, UK). The latter generated $6-\mu \mathrm{L}$ droplets. A step elevation of the infusion reservoir caused a transient inrush of test fluid into the joint as the cavity expanded, then $P_{\mathrm{j}}$ stabilized and the rate of absorption of infusate by the joint reached a steady state within 15 min, as described previously (38).

Flows were measured at the end of each 15-min pe$\operatorname{riod}\left(\dot{Q}_{\text {in }}\right)$ at successive pressures of $\sim 2.5,5.0$, and $7.5 \mathrm{~cm} \mathrm{H} \mathrm{H}_{2} \mathrm{O}$ (below yield pressure) to estimate the physiological conductance of the joint lining, then at $\sim 12,18$, and $24 \mathrm{~cm} \mathrm{H}_{2} \mathrm{O}$ (corresponding to taut effusions) to chart the raised conductances above the yield pressure of the synovial lining (22). Net 
trans-synovial drainage rate $\dot{Q}_{\mathrm{s}}$ was calculated from $\dot{Q}_{\text {in }}$ at the end of each period by subtracting a small correction for the viscoelastic creep of the cavity walls as described in (6). When interpreting changes in $\dot{Q}_{\mathrm{s}}$ it is important to bear in mind that the measured parameter equals a net flow, comprising the interstitial drainage rate out of the cavity minus the capillary filtration rate into it $(23,25)$. The latter becomes significant relative to the drainage rate at low intraarticular pressures and during osmotic infusions into the joint cavity.

\section{Macromolecular Permeation and Synovial Plasma Clearance, $\mathrm{Cl}_{\mathrm{EVA}}$}

A 10-mL injection of Evans blue-labeled albumin (EVA) was given through the ear vein at the start of the experiment. The solution comprised $10 \mathrm{mM}$ Evans blue bound to $120 \mathrm{mg} \mathrm{mL}^{-1}$ bovine serum albumin in Ringer solution (dye binding >99\%) (26). Venous blood was sampled at $30 \mathrm{~min}$ and at the end. $\sim 270 \mathrm{~min}$. At $30 \mathrm{~min}$, and thereafter at the end of each 15-min trans-synovial flow determination, the intraarticular fluid was aspirated and weighed. The EVA contents of the aspirated fluid and centrifuged venous plasma were analyzed by spectrophotometry at $600 \mathrm{~nm}$ (Du-62, Beckman Instruments, Fullerton, CA, USA). From the results the EVA flux from synovial plasma into the joint cavity, $d m / d t$, was calculated as described in (38), then divided by plasma concentration $C_{\mathrm{p}}$ to give the synovial plasma clearance, $\mathrm{Cl}_{\mathrm{EVA}} . C_{\mathrm{p}}$ at a given time point was calculated by linear interpolation between the plasma concentrations at 30 and $270 \mathrm{~min}$.

\section{Intraarticular Half-Life of Rapidly Diffusible Solutes}

The intraarticular concentration of a small, rapidly diffusible solute such as GRGDTP (601.6 Da) decavs fairly rapidly in vivo due to clearance by the microcirculation. For solutes of size 370-582 Da the measured intraarticular half-life is 14-24 min (37). For this reason, and also for the purpose of EVA sampling, the joint was aspirated as completely as possible every $15 \mathrm{~min}$ and refilled with fresh solution. In this way the fall in intraarticular concentration was limited to $\leq \frac{1}{2}$ the nominal concentration before the next top-up.

\section{Materials}

The specificity of the hexapeptide $\mathrm{H}_{2} \mathrm{~N}$-Gly-Arg-GlyAsp-Thr-Pro-COOH (GRGDTP) is well documented
$(11,46)$. The GRGDTP (601.6 Da) was obtained from Novabiochem (Nottingham, UK), Calbiochem (Nottingham. UK) and Advanced Biotechnology Centre (ABC, Faculty of Medicine, Imperial College, London, UK). The infused concentration was $3 \mathrm{mM}$ in an isotonic physiological salt solution (see below) for the first 2 pressure-flow studies and $10 \mathrm{mM}$ (6 $\mathrm{mg} \mathrm{mL} \mathrm{mL}^{-1}$ ) for all other studies. A concentration above the literature values for cell-binding inhibition and endothelial permeability elevation (1$\left.2 \mathrm{mg} \mathrm{mL} \mathrm{m}^{-1}\right)(11,17,40)$ was selected to allow for the unavoidable decay in intraarticular concentration over $15 \mathrm{~min}$ in vivo. The number of experiments was limited by the high cost of synthetic hexapeptide and the large quantities required for work on a rabbit joint in vivo. For the same reason non-RGD hexapeptide was not used as a control in the present study; however, studies by others on cultured cells (7) and isolated venules (57) confirm that non-RGD hexapeptide is biologically inactive. The physiological salt solution was a sterile, pyrogen-free mammalian Ringer solution comprising $147 \mathrm{mM} \mathrm{Na}^{+}, 4 \mathrm{mM} \mathrm{K}^{+}, 2 \mathrm{mM} \mathrm{Ca}^{2+}$, and $153 \mathrm{mM} \mathrm{Cl}^{-}$(Baxter Healthcare, Thetford, Norfolk, UK) of osmolarity $306 \mathrm{mosm} / \mathrm{L}$. Osmotic stress was induced by the addition of $147 \mathrm{mmol} \mathrm{NaCl} / \mathrm{L}$ to the Ringer solution to raise its total osmolarity to $600 \mathrm{mosm} / \mathrm{L}$.

\section{Statistical Methods}

The effect of treatment on $\mathrm{Cl}_{\mathrm{EVA}}-$ time, $P_{\mathrm{j}}$-time, and $P_{\mathrm{j}}-\dot{Q}_{\mathrm{s}}$ relations was assessed by 2 -way analysis of variance (ANOVA). Changes in slope or intercept were assessed by linear regression analysis, paired $t$ test, and analysis of covariance (ANCOVA) using GraphPad Prism (San Diego, California). To compare flows at identical pressures (since $P_{\mathrm{j}}$ varied a little between experiments), flows were interpolated to standard pressures by linear interpolation between the two bounding measurements. Other results were compared using 1-way ANOVA with Neuman-Keuls post hoc multiple comparison test as appropriate, taking $p \leq .05$ as a significant difference. Means and slopes are followed by their standard errors throughout.

\section{RESULTS}

We describe first the changes in transendothelial albumin permeation, then changes in capillary filtration rate as revealed by changes in $d P_{\mathrm{j}} / d t$, and finally 
changes in interstitial matrix conductance as revealed by changes in $d \dot{Q}_{\mathrm{s}} / d P_{\mathrm{j}}$.

\section{Permeation of EVA from Plasma into the Joint Cavity}

Samples of intraarticular fluid from joints infused with isotonic Ringer solution (15 joints) or $10 \mathrm{mM}$ GRGDTP alone (6 joints) or hyperosmolar Ringer solution (8 joints) were almost colorless. By contrast, samples aspirated from joints infused with $10 \mathrm{mM}$ GRGDTP in hyperosmolar Ringer solution $(n=5$ joints $)$ were visibly blue from $30-45 \mathrm{~min}$ onward, showing that GRGDTP and hyperosmolarity acted synergistically to cause a relatively rapid, sustained increase in transendothelial macromolecular permeation (Figure 1A). Two-way ANOVA of the $\mathrm{Cl}_{\mathrm{EVA}}$-time results confirmed that treatment with GRGDTP plus hyperosmolarity significantly raised plasma EVA clearance compared to hyperosmolarity alone $(p<.002)$, and that time did not significantly influence the clearance value $(p=.81)$, i.e., the increase in EVA permeation was sustained over $\sim 2 \mathrm{~h}$. By contrast, treatment with GRGDTP in isotonic Ringer solution did not significantly increase $\mathrm{Cl}_{\mathrm{EVA}}$ compared with the isotonic control joints $(p=.87,2$-way ANOVA) (Figure 1B).

The mean $\mathrm{Cl}_{\mathrm{EVA}}$ in joints treated with GRGDTP plus hyperosmolarity was $15.9 \pm 4.8 \mu \mathrm{L} \mathrm{h}^{-1}(n=5$ joints) (Figure 1C). This was 3.2 times higher than the mean $\mathrm{Cl}_{\mathrm{EVA}}$ in joints infused with hyperosmolar Ringer solution, namely $4.9 \pm 1.5 \mu \mathrm{L} \mathrm{h}^{-1}(n=8$ joints) ( $p=.01,1$-way ANOVA). Five of the 8 hyperosmolar experiments were paired with GRGDTP plus hyperosmolarity in the opposite joint; the $\mathrm{Cl}_{\mathrm{EVA}}$ was greater on the GRGDTP-treated side in all 5 cases. The $\mathrm{Cl}_{\mathrm{EVA}}$ values in joints receiving hyperosmolar Ringer solution, isotonic Ringer solution $(7.1 \pm 0.8$ $\mu \mathrm{L} \mathrm{h}^{-1}, n=15$ joints), and GRGDTP in isotonic Ringer $\left(7.0 \pm 2.3 \mu \mathrm{L} \mathrm{h}^{-1}, n=6\right.$ joints $)$ were not significantly different from each other $(p>.05$, Newman-Keuls multiple comparison test). The effect of GRGDTP in hyperosmolar Ringer was significantly greater than the effect of GRGDTP in isotonic Ringer $(p<.05$, Neuman-Keuls test). Due to the high cost of synthetic peptide and the large amounts required, it was not feasible to evaluate the doseresponse relations.

The fractional albumin extraction from synovial microvessels can be calculated as $\mathrm{Cl}_{\mathrm{EVA}}$ divided by the synovial plasma flow, which we previously estimated to be $45-90 \mu \mathrm{L} \mathrm{min}{ }^{-1}(38)$. The low extraction in control joints, $0.13-0.26 \%$, indicated that the basal microvascular permeability to plasma protein was low despite the presence of fenestrations, in keeping with an earlier determination of the albumin reflection coefficient (20). The extraction increased to $0.29-0.59 \%$ in joints treated with GRGDTP plus hyperosmolarity, but this is still an order of magnitude less than the extraction following $\mathrm{F}$-actin disruption, namely $3-6 \%(38)$.

\section{Effect of RGD and Hyperosmolarity on the Intraarticular Pressure-Time Relation}

We have shown previously that increases in synovial capillary filtration rate manifest themselves by a reduction or even reversal of the decay of intraarticular pressure $P_{\mathrm{j}}$ with time following a small intraarticular bolus injection, because increased filtration into the cavity offsets drainage out of it (37); see Methods. A 200- to 300- $\mu \mathrm{L}$ bolus of isotonic Ringer solution, or GRGDTP $(10 \mathrm{mM})$ in Ringer solution, was injected to raise $P_{\mathrm{j}}$ to $\sim 1.5-2.0 \mathrm{~cm} \mathrm{H}_{2} \mathrm{O}$ and generate a net trans-synovial outflow. $P_{\mathrm{j}}$ decayed with time because the trans-synovial drainage rate exceeded capillary filtration into the cavity (Figure 2A). The decay in $P_{\mathrm{j}}$, and hence net volume loss, was only marginally less in joints that received GRGDTP ( $n=7$ joints) than in those receiving plain Ringer solution $(n=7)$. The difference was $0.33 \pm 0.01 \mathrm{~cm}$ $\mathrm{H}_{2} \mathrm{O}$ over 30 min $(p=.08,2$-way ANOVA). The results indicated that GRGDTP in isotonic fluid reduced the net trans-synovial outflow in vivo only slightly and with marginal statistical significance.

Experiments to compare Ringer and GRGDTP $P_{\mathrm{j}}-$ time curves were also carried out immediately after arresting the heart by an intravenous pentobarbitone overdose. The aims were (1) to test whether the marginal GRGDTP-induced reduction in net outflow in vivo still occurred after capillary perfusion had ceased, and (2) to test whether RGD-mediated cellmatrix bonds influence extravascular fluid pressure (by opposing the gel swelling pressure; see Introduction and reference 41). The intraarticular bolus was reduced to $100-150 \mu \mathrm{L}$ so that the $P_{\mathrm{j}}$-time relation started close to atmospheric pressure. With both test solutions $P_{\mathrm{j}}$ fell to just below atmospheric pressure within minutes and stabilized at a slightly subatmospheric pressure beyond 5-10 min. The mean fall in $P_{\mathrm{j}}$ in 3 GRGDTP-treated joints, $-0.73 \mathrm{~cm} \mathrm{H} \mathrm{H}_{2} \mathrm{O}$, was not significantly different from that in the Ringer controls, $-0.89 \mathrm{~cm} \mathrm{H}_{2} \mathrm{O}(p=.23,2$-way ANOVA $)$. The $P_{\mathrm{j}}$-versus-time regression slopes beyond $5 \mathrm{~min}$ were not significantly different from zero, either for 

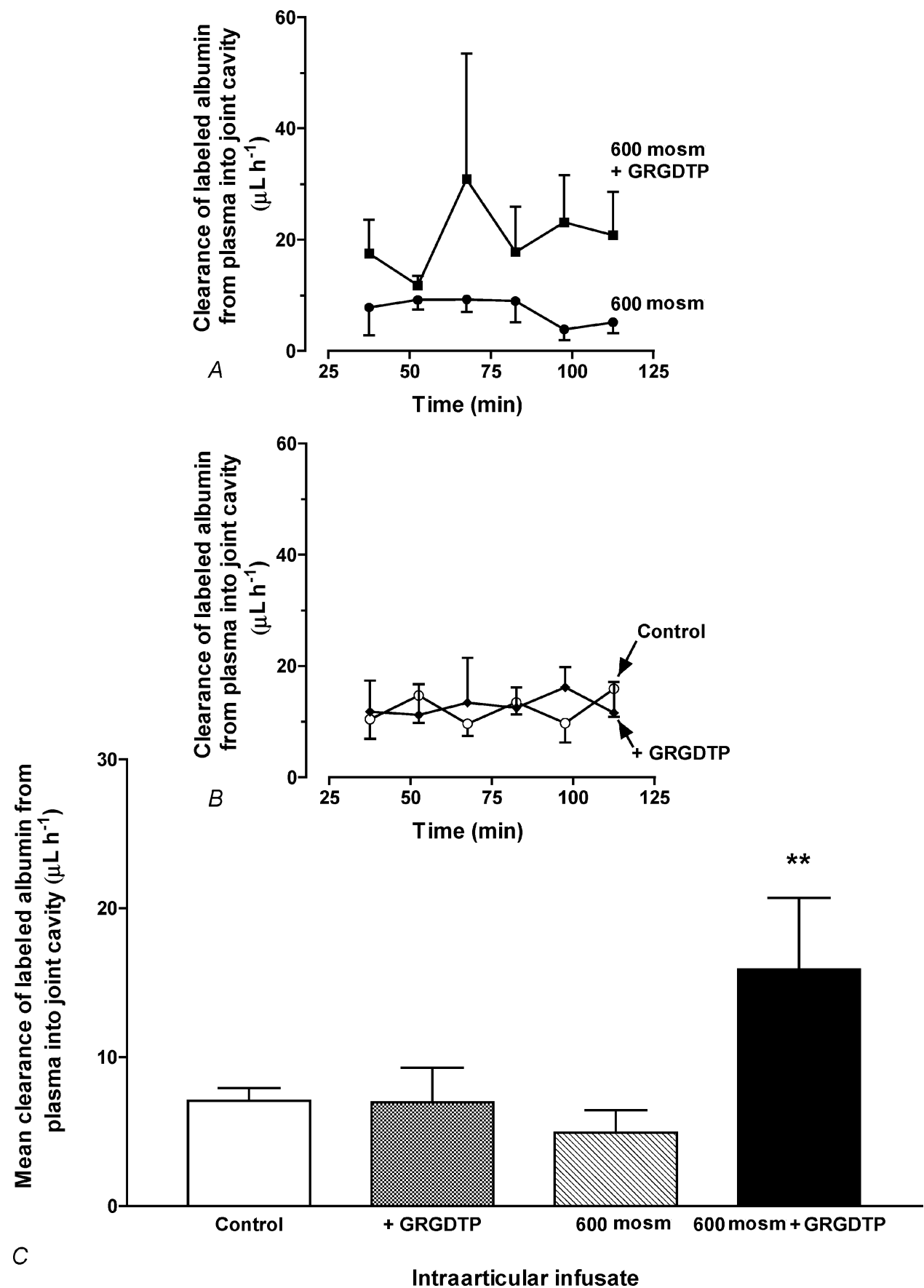

Figure 1. Permeation of Evans blue-labeled plasma albumin into the joint cavity expressed as plasma clearance $\left(\mathrm{Cl}_{\mathrm{EVA}}\right)$ i.e., flux/plasma concentration (mean \pm SEM). $(A)$ Time course of clearance in 8 joints infused with hyperosmolar Ringer solution (600 mosm) and 5 joints infused with GRGDTP peptide in hyperosmolar Ringer plus $(p<.002,2$-way ANOVA). (B) Time course of clearance in joints infused with isotonic Ringer solution $(n=15)$ or GRGDTP in isotonic Ringer solution $(n=6)\left(p=.81,2\right.$-way ANOVA). $(C)$ Time-averaged $\mathrm{Cl}_{\mathrm{EVA}}$ for the 4 treatments: isotonic Ringer solution $(n=15$ joints), GRGDTP in isotonic Ringer solution ( $n=6$ joints), 600 mosm Ringer solution $(n=8$ joints), and GRGDTP in 600 mosm Ringer solution $\left(n=5\right.$ joints). $\mathrm{Cl}_{\mathrm{EVA}}$ for last group was significantly higher than other three $\left({ }^{* *} p=.01,1\right.$-way ANOVA $)$. Differences among the other three groups were not significant $(p>.05$, Neuman-Keuls multiple comparison test). 
A

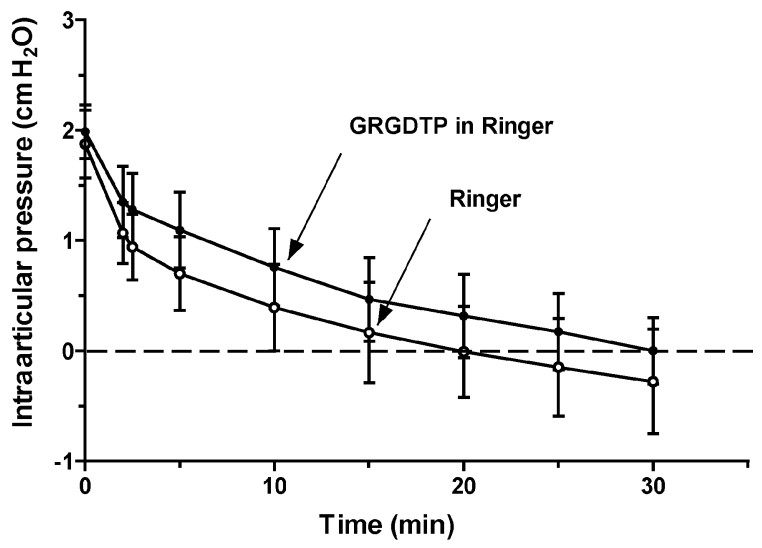

$B$

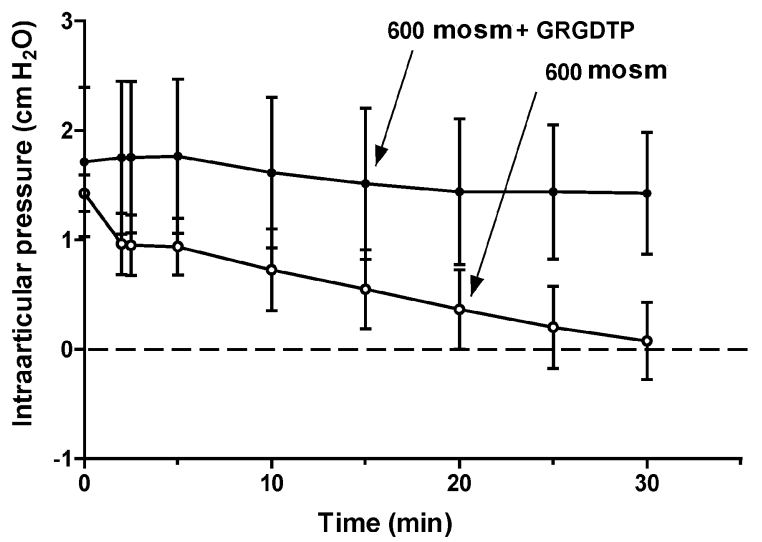

Figure 2. Effect of GRGDTP \pm hyperosmolarity on intraarticular pressure decay (an index of net trans-synovial flow) following a small bolus injection (200-300 $\mu \mathrm{L})$ into the joint cavity (mean $\pm \mathrm{SEM}$ ). (A) GRGDTP in isotonic Ringer solution in vivo $(n=7)$ attenuated the $P_{\mathrm{j}}$ decay marginally relative to Ringer solution $(n=7)(p=.08$, 2-way ANOVA). ( $B$ ) GRGDTP in hyperosmolar Ringer solution in vivo $(n=4)$ greatly attenuated the decay of $P_{\mathrm{j}}$ when compared with hyperosmolar Ringer solution in the contralateral joint $(n=4)(p<.001,2$-way ANOVA $)$ or GRGDTP in isotonic Ringer solution in unpaired joints (A).

Ringer solution $\left(-0.0023 \pm 0.0019 \mathrm{~cm} \mathrm{H}_{2} \mathrm{O} \mathrm{min}^{-1}\right)$ or for GRGDTP $\left(0.0107 \pm 0.0055 \mathrm{~cm} \mathrm{H}_{2} \mathrm{O} \mathrm{m^{-1 }}\right)$. Disruption of the synoviocyte actin cytoskeleton by cytochalasin likewise has no effect on $P_{\mathrm{j}}$ or on synovial interstitial fluid pressure postmortem (37).

As in the EVA clearance experiments, GRGDTP plus hyperosmotic stress caused more striking changes (Figure 2B). In control joints that received a bolus of 600 mosm Ringer solution, $P_{\mathrm{j}}$ decayed from an initial $1.43 \pm 0.17 \mathrm{~cm} \mathrm{H}_{2} \mathrm{O}$ to almost atmospheric pressure in $30 \mathrm{~min}$ ( $n=4$ joints). In the paired, contralateral knees, which received a bolus of GRGDTP in 600 mosm Ringer $(n=4)$, the decay in $P_{\mathrm{j}}$ with time was greatly attenuated, indeed almost halted $(p=.0005,2$-way ANOVA $)$. The mean $P_{\mathrm{j}}$ fell by less than $0.3 \mathrm{~cm} \mathrm{H}_{2} \mathrm{O}$, from $1.71 \pm 0.68 \mathrm{~cm} \mathrm{H}_{2} \mathrm{O}$ at time zero to $1.43 \pm 0.56 \mathrm{~cm} \mathrm{H}_{2} \mathrm{O}$ at $30 \mathrm{~min}$. Moreover, in one of the experiments the pressure ceased to decay at $13 \mathrm{~min}$, reversed direction at $20 \mathrm{~min}$, and thereafter increased slowly with time. We showed previously that the reduction/reversal of $d P_{\mathrm{j}} / d t$ is caused by increased synovial microvascular filtration into the joint cavity, which counterbalances the concomitant fluid drainage (37). The decay of $d P_{\mathrm{j}} / d t$ in joints receiving GRGDTP plus hyperosmolar saline, $-0.009 \pm 0.003 \mathrm{~cm} \mathrm{H}_{2} \mathrm{O} \mathrm{min}^{-1}$ over $10-30 \mathrm{~min}$, was $27 \%$ of that in the joints receiving hyperosmolar saline alone, $-0.033 \pm 0.001 \mathrm{~cm} \mathrm{H}_{2} \mathrm{O} \mathrm{min} \mathrm{m}^{-1}$ $(p=.0002$, ANCOVA $)$. The large change in $d P_{\mathrm{j}} / d t$, along with the substantial increase in $\mathrm{Cl}_{\mathrm{EVA}}$, indicates that GRGDTP increases the flux of water and plasma protein across the endothelial barrier during osmotic stress (see Discussion).

Hyperosmolarity per se reduced the pressure decay only slightly, though significantly, as shown by comparison of the isotonic Ringer curves $(n=7$, mean initial $\left.P_{\mathrm{j}}=1.88 \pm 0.30 \mathrm{~cm} \mathrm{H} \mathrm{H}_{2} \mathrm{O}\right)$ and $600 \mathrm{mosm}$ Ringer curves (unpaired, $n=7$, mean initial $P_{\mathrm{j}}=$ $\left.1.93 \pm 0.52 \mathrm{~cm} \mathrm{H}_{2} \mathrm{O}\right) . P_{\mathrm{j}}$ after the hyperosmolar bolus decayed less rapidly and remained on average $0.69 \pm 0.04 \mathrm{~cm} \mathrm{H}_{2} \mathrm{O}$ higher than the isotonic values over $30 \mathrm{~min}$ ( $p=.008,2$-way ANOVA). Similarly, 2 previous studies showed that hyperosmolar intraarticular solutions attenuate $P_{\mathrm{j}}$ decay in vivo and that this effect depends on synovial microvascular filtration, since it is abolished by circulatory arrest $(25,47)$.

\section{Effect of GRGDTP on the Trans-Synovial Flow-Pressure Relation}

In the following two-cannula experiments $P_{\mathrm{j}}$ was "clamped" at various, raised levels by continuous intraarticular infusion and the corresponding net trans-synovial drainage rate $\dot{Q}_{\mathrm{s}}$ was measured; see Methods. Under these conditions the $\dot{Q}_{\mathrm{s}}-P_{\mathrm{j}}$ relation is dominated by the conductance of the interstitial drainage pathway, because most of the fluid draining out of the cavity bypasses the synovial capillaries and enters the loose areolar subsynovium where the initial lymphatic plexus is located $(22,23)$. The $\dot{Q}_{\mathrm{s}}-P_{\mathrm{j}}$ relation for isotonic saline across synovium is 


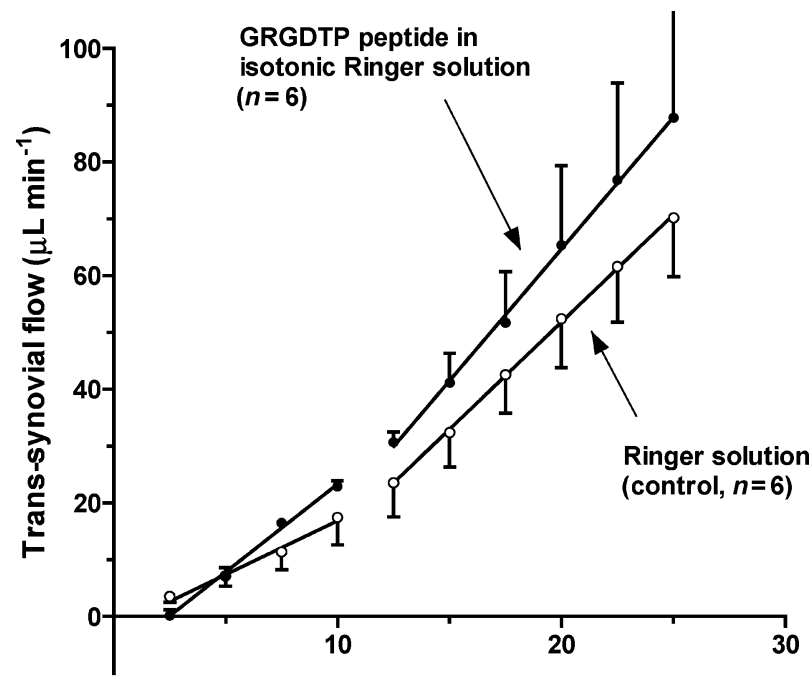

Intraarticular pressure $\left(\mathrm{cm} \mathrm{H}_{2} \mathrm{O}\right)$

Figure 3. Effect of GRGDTP in isotonic Ringer solution $(\bullet)$ on relation between net trans-synovial drainage rate and joint fluid pressure, compared with relation for Ringer solution in contralateral joint of same animal (o). Mean \pm SEM, 6 animals; some error bars fall inside symbol. GRGDTP increased the steepness of the relation i.e., the synovial lining hydraulic conductance (linear regression analysis; see Results).

conventionally approximated by 2 straight lines, with a steepening above $\sim 8-10 \mathrm{~cm} \mathrm{H}_{2} \mathrm{O}$ (yield pressure) caused by increased interstitial hydraulic conductivity and stretch $(22,23)$. The slope increased significantly above yield pressure for all the infusates in this study ( $p<.0001$, ANCOVA) (Figures $3-5)$.

Figure 3 shows the trans-synovial outflow $\dot{Q}_{\mathrm{s}}$ as a function of $P_{\mathrm{j}}$ for 6 joints infused with GRGDTP in isotonic Ringer solution and 6 contralateral joints of the same animals infused with isotonic Ringer solution. GRGDTP increased the slope and shifted the intercept of the relation. The $P_{\mathrm{j}}$ intercept (pressure for zero net trans-synovial flow) was raised by $1.7 \mathrm{~cm} \mathrm{H}_{2} \mathrm{O}(p=.02$, paired $t$ test, $n=6)$. At the lowest pressure, $2.5 \mathrm{~cm} \mathrm{H} \mathrm{H}_{2} \mathrm{O}$, GRGDTP reduced the net outflow from $3.5 \pm 1.0 \mu \mathrm{L} \mathrm{min}^{-1}$ (control) to $0.1 \pm 1.1 \mu \mathrm{L} \mathrm{min} \min ^{-1}(p=.05$, paired $t$ test $)$. These observations support the inference from Figure $2 \mathrm{~A}$ that GRGDTP treatment reduces the net transsynovial outflow at low pressures.

At all pressures $>5 \mathrm{~cm} \mathrm{H}_{2} \mathrm{O}$, GRGDTP treatment raised the net trans-synovial outflow $(p=.04,2$ way ANOVA), because it increased the slope of the relation $d \dot{Q}_{\mathrm{s}} / d P_{\mathrm{j}}$ in all 6 pairs of joints. GRGDTP increased the regression slope $d \dot{Q}_{\mathrm{s}} / d P_{\mathrm{j}}$ below yield

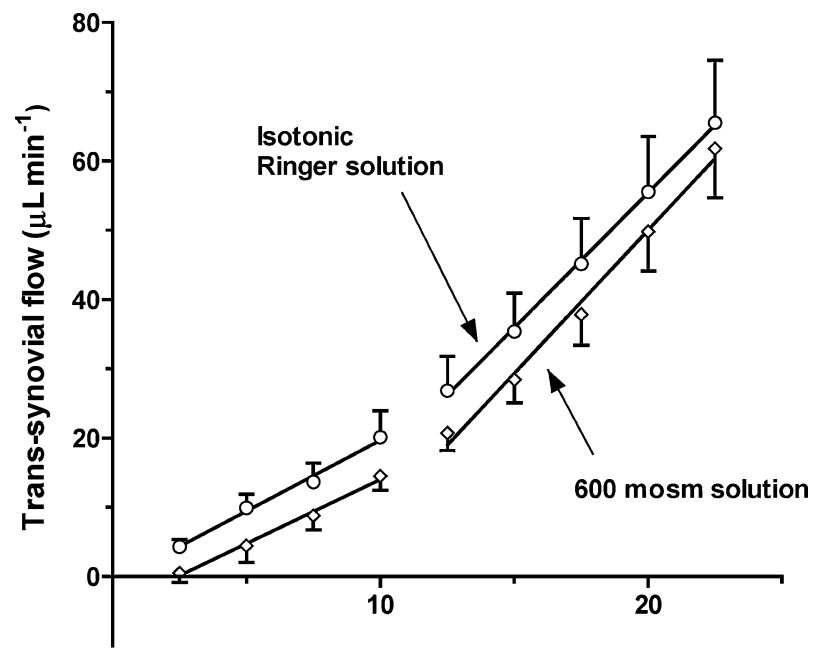

Intraarticular pressure $\left(\mathrm{cm} \mathrm{H}_{2} \mathrm{O}\right)$

Figure 4. Comparison of effect of hyperosmotic Ringer solution $(\diamond$, mean \pm SEM, $n=7$ joints) and isotonic Ringer solution (o, $n=9$, unpaired studies) on net trans-synovial outflow. Hyperosmolarity reduced net outflow significantly $(p=.02,2$-way ANOVA $)$ due to a change of intercept, but had no significant effect on slope. For linear regression parameters see Results.

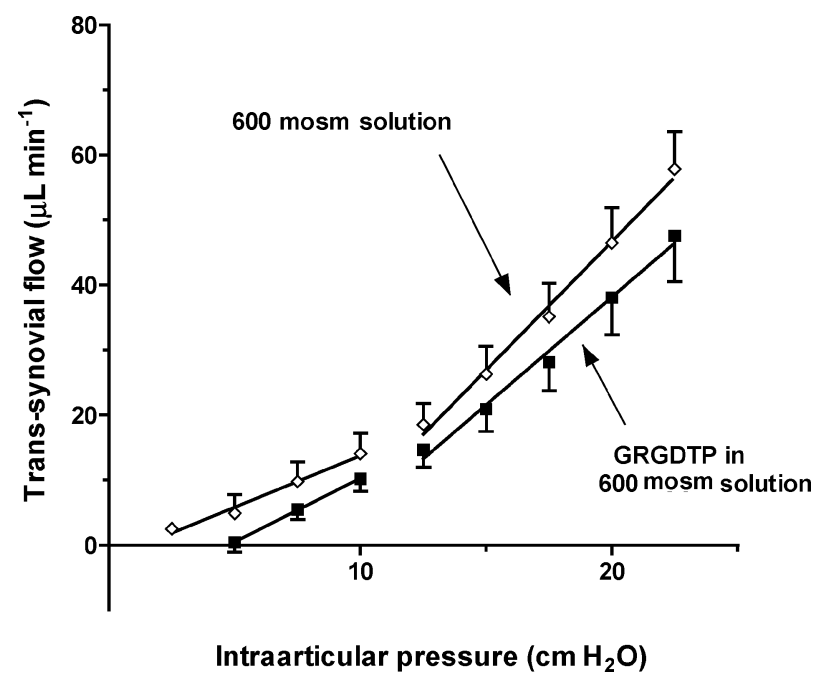

Figure 5. Effect of GRGDTP in hyperosmolar Ringer solution $(\mathbf{\square}, n=4$ joints, mean $\pm \mathrm{SEM})$ on relation between net trans-synovial outflow and joint fluid pressure, compared with hyperosmolar Ringer solution in contralateral joints of same animal $(\diamond, n=4)$. GRGDTP in hyperosmolar solution significantly increased the pressure intercept but the change in slope was not significant; see Results. 
pressure by $71 \%$, from a mean of $1.50 \pm 0.41 \mu \mathrm{L}$ $\min ^{-1} \mathrm{~cm} \mathrm{H}_{2} \mathrm{O}^{-1}$ (Ringer solution, $n=6$ joints) to $2.56 \pm 0.39 \mu \mathrm{L} \mathrm{min}{ }^{-1} \mathrm{~cm} \mathrm{H}_{2} \mathrm{O}^{-1}$ (GRGDTP, $n=6$ joints) ( $p=.02$, paired $t$ test). The substantial effect of GRGDTP in isotonic Ringer on synovial lining hydraulic conductance $d \dot{Q}_{\mathrm{s}} / d P_{\mathrm{j}}$ contrasted with its lack of effect on transendothelial plasma EVA clearance (Figure 1). Above yield pressure the increase in slope $d \dot{Q}_{\mathrm{s}} / d P_{\mathrm{j}}$ evoked by GRGDTP did not reach statistical significance; the slope was $5.77 \pm$

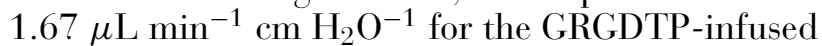
joints and $3.90 \pm 0.46 \mu \mathrm{L} \mathrm{min}^{-1} \mathrm{~cm} \mathrm{H}_{2} \mathrm{O}^{-1}$ for the Ringer-infused joints $(n=6$ joints; $p=.36$, paired $t$ test).

\section{Effect of Hyperosmolarity on the Trans-Synovial Flow-Pressure Relation}

Infusions of 600 mosm Ringer solution were carried out as controls for the GRGDTP-osmotic stress experiments (next section). Figure 4 compares the $P_{\mathrm{j}}-$ $\dot{Q}_{\mathrm{s}}$ relations in isotonic $(n=9)$ and hyperosmolarinfused joints ( $n=7$, unpaired). Hyperosmolarity reduced the net trans-synovial outflows throughout the pressure range $(p=.02,2$-way ANOVA), due to an almost parallel rightward shift of the $P_{\mathrm{j}}-\dot{Q}_{\mathrm{s}}$ relation. Hyperosmolarity shifted the $y$-axis intercept from $-0.46 \pm 3.07 \mu \mathrm{L} \mathrm{min}{ }^{-1}$ for the isotonic control $\left(x\right.$ intercept $\left.0.23 \mathrm{~cm} \mathrm{H}_{2} \mathrm{O}\right)$ to $-4.50 \pm 2.38 \mu \mathrm{L}$ $\min ^{-1}\left(x\right.$ intercept $\left.2.43 \mathrm{~cm} \mathrm{H} \mathrm{H}_{2} \mathrm{O}\right)(p=.003$, ANCOVA). Parallel shifts of this nature are characteristic of osmotic forces acting on a semipermeable membrane, i.e., capillary wall; see Discussion.

Hyperosmolarity had no significant effect on slope $d Q_{\mathrm{s}} / d P_{\mathrm{j}}$. The slopes below yield pressure averaged $1.58 \pm 0.29 \mu \mathrm{L} \mathrm{min}{ }^{-1} \mathrm{~cm} \mathrm{H}_{2} \mathrm{O}^{-1}$ for hyperosmolar infusions $(n=7$ joints) and $1.72 \pm 0.34 \mu \mathrm{L}$ $\mathrm{min}^{-1} \mathrm{~cm} \mathrm{H}_{2} \mathrm{O}^{-1}$ for isotonic infusions $(n=9$ joints $)$ ( $p=.76$, unpaired $t$ test). The slopes above yield pressure averaged $4.14 \pm 0.53 \mu \mathrm{L} \mathrm{min}^{-1} \mathrm{~cm} \mathrm{H}_{2} \mathrm{O}^{-1}$ for hyperosmolar infusions $(n=7$ joints) and $3.90 \pm$ $0.46 \mu \mathrm{L} \mathrm{min} \mathrm{m} \mathrm{H}_{2}^{-1} \mathrm{Cm}^{-1}$ for isotonic infusions ( $p=.74$, unpaired $t$ test). Hyperosmolarity per se did not, therefore, change the hydraulic conductance of the synovial lining significantly.

\section{Effect of GRGDTP Plus Osmotic Stress} on Trans-Synovial Flow-Pressure Relation

Figure 5 summarizes the results of 4 paired experiments in which GRGDTP in 600 mosm Ringer solution was infused into one joint and 600 mosm Ringer solution into the contralateral joint of the same animal. The addition of GRGDTP reduced the net transsynovial outflows slightly but significantly over the whole pressure range ( $p=.003,2$-way ANOVA). The reduction was brought about by a downward shift in the $y$ intercept in every case, from a mean of $-1.8 \pm 2.9 \mu \mathrm{L} \mathrm{min}{ }^{-1}$ for the hyperosmolar controls to $-9.3 \pm 3.5 \mu \mathrm{L} \mathrm{m^{-1 }}$ for GRGDTP plus hyperosmolarity ( $p=.01$, paired $t$ test, $n=4$ animals). The reduced net outflows at supraatmospheric pressures and the negative shift in the $y$-intercept (i.e., increased trans-synovial flow directed into the joint cavity at atmospheric pressure) are attributed to increased microvascular filtration (see Discussion).

The $41 \%$ increase in the mean slope below yield pressure, from $1.18 \pm 0.39 \mu \mathrm{L} \mathrm{min}{ }^{-1} \mathrm{~cm} \mathrm{H}_{2} \mathrm{O}^{-1}$ for the hyperosmolar controls to $1.66 \pm 0.44 \mu \mathrm{L} \mathrm{min}^{-1} \mathrm{~cm}$ $\mathrm{H}_{2} \mathrm{O}^{-1}$ for GRGDTP in hyperosmolar Ringer solution, was not statistically significant $(p=.5$, paired $t$ test, $n=4$ animals). Slope analysis using pooled raw data confirmed this (GRGDTP in hyperosmolar

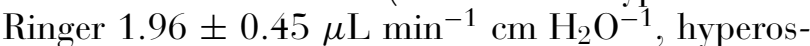
molar controls $1.56 \pm 0.43 \mu \mathrm{L} \mathrm{m^{-1 }} \mathrm{cm} \mathrm{H}_{2} \mathrm{O}^{-1}$; $p=.58$, ANCOVA: $n=16)$. There was likewise no significant difference in slope above yield pressure,

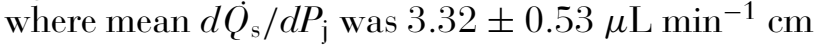
$\mathrm{H}_{2} \mathrm{O}^{-1}$ for GRGDTP in hyperosmolar solution and $3.94 \pm 0.31 \mu \mathrm{L} \mathrm{min}{ }^{-1} \mathrm{~cm} \mathrm{H}_{2} \mathrm{O}^{-1}$ for the paired hyperosmolar controls ( $p=.39$, paired $t$ test: $n=4$ animals).

\section{DISCUSSION}

The principal positive findings were that in the absence of osmotic stress, GRGDTP increased the transsynovial drainage rate per unit intraarticular pressure (interstitial matrix conductance) but had no effect on plasma albumin permeation into the joint cavity (endothelial permeation). Under conditions of osmotic stress, GRGDTP increased albumin clearance from synovial plasma into the joint cavity, almost arrested the usual intraarticular pressure decay after a small bolus injection, and reduced the net transsynovial drainage rate over a wide range of intraarticular pressure. We focus first on RGD-induced endothelial changes, then on RGD-induced interstitial matrix changes.

\section{Contribution of RGD Sequence to Fenestrated Endothelial Barrier Function}

The fenestrated endothelium of synovial capillaries is the major barrier to plasma protein entry into the 
joint cavity $(20,38)$. The breakdown of this barrier in arthritis leads to the formation of large, proteinrich arthritic effusions (53). A partial breakdown of the barrier is inferred from the 3 -fold increase in $\mathrm{Cl}_{\mathrm{EVA}}$ in response to GRGDTP plus osmotic stress (Figure 1A). An alternative interpretation, namely that the increased $\mathrm{Cl}_{\mathrm{EVA}}$ was caused by increased convective transport evoked by the interstitial hyperosmolarity, was excluded by the control observation that 600 mosm Ringer solution did not raise $\mathrm{Cl}_{\text {EVA }}$ (Figure 1C). Since GRGDTP in isotonic solutions had no effect on $\mathrm{Cl}_{\mathrm{EVA}}$ (Figure 1B), it appears that both a reduction in endothelial tethering and an increase in endothelial cytoskeletal stress may be necessary for the moderate permeability increase.

Increases in endothelial permeability to macromolecules are commonly accompanied by increases in hydraulic permeability and filtration rate $(10,14$, $32,44)$. Increased microvascular filtration was evident from the near abolition of $P_{\mathrm{j}}$ decay by GRGDTP plus osmotic stress (Figure 2). In these experiments external fluid was not infused continuously, so $P_{\mathrm{j}}$ decayed because joint fluid outflow through the parallel interstitial drainage pathway exceeded the capillary filtration rate into the joint cavity (23). The decav rate is reduced or reversed when increased capillary filtration rate counterbalances or exceeds the cavity drainage rate. Similarly, moderate disruption of the synovial endothelial barrier by $25 \mu \mathrm{M}$ cytochalasin D attenuates $P_{\mathrm{j}}$ decay, while gross disruption by $>50 \mu \mathrm{M}$ cytochalasin $\mathrm{D}$ causes a slow rise in $P_{\mathrm{j}}$ (37). The vascular origin of the attenuation/reversal of $d P_{\mathrm{j}} / d t$ was confirmed by circulatory arrest, which abolishes such responses (37). Increased microvascular filtration was also evident from the rightward shift of the trans-synovial flowpressure relation (Figure 5), as discussed later.

The effect of GRGDTP in isotonic solution on $P_{\mathrm{j}}$ decay was slight and of marginal statistical significance (Figure 2A), and was not accompanied by any increase in macromolecular permeability (Figure 1B). Since the attenuation of $P_{\mathrm{j}}$ decay was not evident after circulatory arrest, it may (if significant at all) be due to a slight rise in capillary filtration rate elicited by the osmotic pressure of $10 \mathrm{mM}$ GRGDTP, although the effective osmotic pressure of the latter will be slight due to the low fenestral reflection coefficient for crystalloids (20). A hyperosmolar solution of chondroitin sulfate causes a more marked, circulationdependent attenuation of $P_{\mathrm{j}}$ decay (47), but chondroitin sulfate $(58,800 \mathrm{Da})$ is a larger molecule than
GRGDTP with, presumably, a higher endothelial osmotic reflection coefficient.

\section{Comparison with Previous Studies of RGD-Endothelium Interaction}

The present results are the first, to the best of our knowledge, to reveal a role for RGD-mediated bonds in fenestrated, as opposed to continuous, endothelium. Although the RGD-mediated bonds clearly influence the fenestrated endothelium permeability, this is apparent only when the endothelium is subjected to a large osmotic stress. Even then the effect is a relatively modest 3 -fold increase, in contrast to the 25-fold increase in albumin clearance that follows endothelial F-actin disruption by cytochalasin D (38). These findings parallel those of an earlier study of continuous endothelium in situ by Kajimura and Curry (17). They found that RGD-peptide in hyperosmolar saline, but neither alone, increased the hydraulic conductance of amphibian venular endothelium, though only moderately. The relatively small effects reported here and in (17), on intact microvessels in situ in both cases, contrast with the effect on cultured endothelium in vitro, where RGD-sequence peptide greatly increases the macromolecular and hydraulic permeability in the absence of additional osmotic stress $(7,21,40)$. The difference could be due to the use of purified artificial substrata in endothelial cultures and/or changes in integrin expression by cultured endothelium. Functional differences between endothelium in vitro and in vivo are also indicated by the fact that hyperosmolarity per se raises the permeability of cultured pulmonary artery endothelium (50) but neither frog mesenteric microvessels in vivo $(17,18)$ nor rabbit synovial microvessels in vivo (Figure 1). These results reinforce the need for great caution when applying results obtained in culture to living vessels in situ.

More puzzling is the contrast between the results on microvessels in situ (17,18, and here) and results on isolated coronary venules, where RGD-sequence peptide without added osmotic stress raised the macromolecular permeability up to 4.5-fold (57). The difference in responsiveness to isotonic RGD might be due to increased endothelial fragility in isolated venule segments, due to the unavoidable dissection and the $1 \mathrm{~h}$ of preperfusion. Alternatively, the difference might be related to tissue/species differences in integrin and matrix expression. It seems clear, however, from the present results and those in (17), that there is a redundancy of endothelial attachment 
bonds in both continuous and fenestrated microvessels in situ, so that disruption of RGD-mediated bonds alone does not affect permeability unless an additional stress is imposed, and even then the permeability increase is only moderate.

\section{Mechanisms by Which RGD Sequence Peptide Influences the Endothelial Barrier}

The simplest explanation for the effects of RGD plus osmotic stress would be that RGD-peptide reduces the endothelial adhesion to the basal lamina. When the reduced tethering is combined with an increase in endothelial tension brought about by hyperosmolar cell volume reduction, the endothelial distortion triggers macromolecule-permeable pathway formation. The pathway might be intercellular or transcellular channels $(32,44,57)$, perhaps related to vesiculo-vacuolar organelles (10). The RGD-dependent ligands fibronectin and vitronectin appear to be only minor components of the basal lamina quantitatively (28), but may be important because their counterligands, the integrins $\alpha_{5} \beta_{1}$ and $\alpha_{V} \beta_{1,3}$, are concentrated at the margins of the paracellular pathway, at least in cultured endothelium (21). Of the main quantitative constituents of basal lamina (laminin, type IV collagen, perlecan), only the perlecan-endothelium bond is partly RGD mediated (30). The lack of effect of isotonic GRGDTP is attributed to the known endothelial expression of nonRGD-dependent integrins, such as $\alpha_{2} \beta_{1}$, which bind to the major basal lamina constituents, collagen and laminin. Such bonds presumably provide sufficient endothelial tethering to maintain barrier integrity in low-stressed RGD-blocked endothelium in situ.

The above mechanical hypothesis may well prove overly simplistic, because Kajimura and Curry (17) showed that the effect of GRGDTP plus osmotic stress is abolished by $60-100 \mathrm{mM} \mathrm{K}{ }^{+}$. The high $\left[\mathrm{K}^{+}\right]$depolarizes the cell, which reduces the electrochemical force driving extracellular $\mathrm{Ca}^{2+}$ entry. Increased endothelial $\left[\mathrm{Ca}^{2+}\right]_{\mathrm{i}}$ activates the cGMP-protein kinase $\mathrm{G}$ cascade, leading to a dissociation of junctional proteins from the cytoskeleton and increased permeability $(14,34)$. Intracellular $\mathrm{Ca}^{2+}$ concentration rises in renal epithelial cells exposed to RGD peptide-coated beads (51). Moreover, increased integrin stress triggers $\mathrm{Ca}^{2+}$ influx into fibroblasts (12), causes tyrosine phosphorylation of cytoskeletally anchored proteins (48), and alters integrin-related kinase activity $(8.45)$. Synovial endothelial barrier integrity is heavily dependent on the actin cytoskeleton (38), which is linked to intercellular junctional proteins and to integrins. Taking the above facts into account, a possible working hypothesis is that changes in integrin stress induced by RGD and hyperosmolarity trigger changes in kinase activity and a rise in endothelial $\left[\mathrm{Ca}^{2+}\right]_{\mathrm{i}}$ which leads via kinase cascades to endothelial barrier modulation.

\section{Interstitial Matrix-Parenchymal Cell Bonds as Determinants of Interstitial Resistance}

GRGDTP in isotonic Ringer solution altered both the slope and the intercept of the net flow-pressure relation. The small but significant increase in the pressure intercept at zero net trans-synovial flow (Figure 3). along with the marginal reduction in $P_{\mathrm{j}}$ decay in Figure $2 \mathrm{~A}$ and its abolition by circulatory arrest, may be due to a small effective osmotic pressure exerted by interstitial GRGDTP on the abluminal face of the fenestrated capillaries, of the order $\leq 0.9 \%$ of the van't Hoff osmotic pressure. A consequent rise in capillary filtration rate will significantly reduce the measured net flow $\dot{Q}_{\mathrm{s}}$ at low $P_{\mathrm{j}}$, because the rate of fluid absorption from the infusion reservoir $\left(\dot{Q}_{\mathrm{s}}\right)$ equals the total fluid drainage through the interstitial pathway minus the fluid input into the joint cavity by the synovial capillary bed. Similar osmotic effects have been demonstrated with other hyperosmolar solutions in joints $(25,47)$.

Of greater physiological interest is the $71 \%$ increase in slope $d \dot{Q}_{\mathrm{s}} / d P_{\mathrm{j}}$ below yield pressure evoked by GRGDTP in isotonic saline. Since endothelial permeability was unchanged (Figure 1), and the net trans-synovial outflow at raised $P_{\mathrm{j}}$ passes mainly through the synovial interstitial pathway $(22,23)$, we conclude that GRGDTP increases the hydraulic conductance of the trans-synovial interstitial pathway. In other words, intact RGD-mediated bonds lower the hydraulic permeability of the normal joint lining 0.58 -fold, and are thus important in the retention of the lubricating synovial fluid inside a joint cavity. Nevertheless, matrix-degrading enzymes produce much bigger, $\geq 400 \%$, increases in synovial conductance (49), so we must also conclude that non-RGD bonds have an even greater role.

Above yield pressure, the slope is governed by the rate at which synovial conductance increases with pressure, rather than conductance per se (22). The conductance increases due to tissue stretch and increased hydration $(24,39)$.

As reviewed in the Introduction, synovial parenchymal cells express the RGD-binding integrins $\alpha_{5} \beta_{1}$ 
(binds fibronectin) and $\alpha_{\mathrm{V}} \beta_{1}$ (binds vitronectin). The increase in $d \dot{Q}_{\mathrm{s}} / d P_{\mathrm{j}}$ evoked by exogenous hexapeptide indicates that disruption of native RGD-integrin bonds increases the freedom of movement of the matrix components, promoting matrix disorganization and increased hydraulic permeability. Bond disruption presumably creates new/larger waterconducting channels, perhaps at the cell margins. Synoviocytes also express non-RGD-dependent integrins such as $\alpha_{1} \beta_{1}$ (binds collagen), so GRGDTP probably causes only partial, selective matrix detachment. This may explain why the conductance increase was modest $(71 \%)$ compared with the much bigger, $\geq 400 \%$, increases produced by matrix degrading enzymes (49).

Hyperosmolarity alone did not affect $d \dot{Q}_{\mathrm{s}} / d P$ (Figure 4), so we conclude that osmotic stress of the parenchymal cells does not raise the interstitial conductance. Similarly, although interstitial hyperosmolarity reduces cell volume in rat abdominal muscle, it has little effect on interstitial hydration and, by implication, conductance (58). The latter group also reported that net trans-peritoneal fluid drainage is reduced by intraperitoneal hypertonicity, because an osmosis-induced microvascular filtration partly offset the hydraulic flow. This parallels the present findings that hyperosmolarity attenuates $P_{\mathrm{j}}$ decay and depresses the net trans-synovial drainagepressure relation (Figure 4). These findings indicate that an osmotic force can partly offset the hydraulic gradient. The similar depression of net trans-synovial outflow by intraarticular hyperosmolar chondroitin sulfate solution is known to be brought about by osmotically increased capillary filtration, because it is abolished by circulatory arrest (47). The magnitude of the intercept displacement in Figure 4 is small due to three factors: the low crystalloid osmotic reflection coefficient of fenestrated endothelium (20), local perifenestral dilution of the osmotic agent by capillary filtrate (23), and the large, parallel leak through synovial interstitium into subsynovium (23).

The effect of GRGDTP in hyperosmotic Ringer solution on the pressure-flow relation (Figure 5) was partly as expected from the above discussion and partly at odds with expectation. The increase in pressure intercept at zero net trans-synovial flow was as expected, because the endothelial permeability increased (Figure 1A) and capillary filtration rate increased (Figure 2B). Puzzlingly, however, the slope $d \dot{Q}_{\mathrm{s}} / d P_{\mathrm{j}}$ increased by only $41 \%$ relative to the hyperosmolar controls (difference not significant), whereas GRGDTP in isotonic Ringer solution increased the slope significantly by $71 \%$. A speculative explanation for the lesser effect of GRGDTP in hyperosmotic solution might be that osmotic shrinkage of the synovial cells caused a reorganization of the matrix biopolymers through non-RGD links, which partly counteracted the effects of integrin-RGD bond disruption.

In conclusion, the study showed that (1) RGDmediated linkages between the fenestrated endothelium and its substratum are necessary to maintain the barrier to plasma albumin and fluid under condition of increased mechanical stress, but are not essential under normal conditions. The latter implies a considerable redundancy of tethering bond types in microvessels in situ, in contrast to the findings of others in vitro (2) RGD-mediated linkages between parenchymal cells and extracellular biopolymers were shown for the first time to contribute to the low hydraulic conductance of interstitial matrix. Maintenance of a low conductance is functionally important in joints because it retains the lubricating fluid inside the cavity. The findings should also underpin our understanding of arthritic effusions, in which increased cytokine levels alter the synovial integrin expression $(35,42,43)$ and high metalloprotease levels may expose normally shielded RGD sequence, e.g., on collagens, and liberate soluble RGD-containing fragments.

\section{REFERENCES}

1. Adelba SM, Daise M, Levine EM, Buck CA. (1989). Identification and characterization of cell-substratum adhesion receptors on cultured human endothelial cells. J Clin Invest 83:1992-2002.

2. Berg A, Rubin K, Reed RK. (2001). Cytochalasin D induces oedema formation and lowering of interstitial fluid pressure in rat dermis. Am J Physiol 281:H7H13.

3. Cheng YF, Kramer RH. (1989). Human microvascular endothelial cells express integrin-related complexes that mediate adhesion to the extracellular matrix. J Cellular Physiol 139:275-286.

4. Cheresh DA. (1987). Human endothelial cells synthesize and express an Arg-Gly-Asp directed adhesion receptor involved in attachment to fibrinogen and von Willebrand factor. Proc Natl Acad Sci USA 84:64716475 .

5. Ciambrone GJ, McKeown LP. (1990). Plasminogen activator inhibitor type I stabilizes vitronectindependent adhesion in HT-1080 cells. J Cell Biol 111:2183-2195.

6. Coleman PJ, Scott D, Mason RM, Levick JR. (1999). Characterization of the effect of high molecular weight 
hyaluronan on trans-synovial flow in rabbit knees. J Physiol 514:265-282.

7. Curtis TM, McKeown-Longo PJ, Vincent PA, Homan SM. Wheatley EM, Saba TM. (1995). Fibronectin attenuates increased endothelial monolayer permeability after RGD peptide, anti- $\alpha_{5} \beta_{1}$ or TNF- $\alpha$ exposure. Am J Physiol 269:L248-L260.

8. Dedhar S, Hannigan GE. (1996). Integrin cytoplasmic interactions and bidirectional membrane signalling. Curr Opin Cell Biol 8:657-669.

9. Dejana E, Corada M, Lampugnani MG. (1995). Endothelial cell-to-cell junctions. FASEB J 9:910-918.

10. Feng D, Nagy JA, Pye K, Haramel I, Dvorak HF, Dvorak AM. (1999). Pathways of macromolecular extravasation across microvascular endothelium in response to VPF/VEGF and other vasoactive mediators. Microcirculation 6:23-44.

11. Gehlsen KR, Argraves WS, Pierschbacher MD, Ruoslahti E. (1988). Inhibition of in vitro tumor cell invasion by Arg-Gly-Asp-containing synthetic peptides. J Cell Biol 106:925-930.

12. Glogauer M, Ferrier J, McCulloch CAG. (1995). Magnetic fields applied to collagen-coated ferric oxide beads induce stretch-activated $\mathrm{Ca}^{2+}$ flux in fibroblasts. Am J Physiol 269:C1093-C1104.

13. Hayman EG, Pierschbacher MD, Ruoslahti E. (1985). Detachment of cells from culture substrate by soluble fibronectin peptides. J Cell Biol 100:1948-1954.

14. He P, Zeng M, Curry FE. (1998). cGMP modulates basal and activated microvessel permeability independently of $\left[\mathrm{Ca}_{\mathrm{i}}^{2+}\right]$. Am J Physiol 274:C1865-C1874.

15. Johansson S. (1996). Non-collagenous matrix proteins. In: Extracellular Matrix, Vol. 2, Molecular Components and Interactions (WD Comper, Ed.). Amsterdam: Harwood Academic, 68-94.

16. Johnson BA, Haines GK, Harlow LA, Koch AE. (1993). Adhesion molecule expression in human synovial tissue. Arthritis Rheum 36:137-146.

17. Kajimura M, Curry FE. (1999). Endothelial cell shrinkage increases permeability through a $\mathrm{Ca}^{2+}$ dependent pathway in single frog mesenteric microvessels. J Physiol 518:227-238.

18. Kajimura M, O'Donnel ME, Curry FE. (1997). Effect of cell shrinkage on permeability of cultured bovine aortic endothelial and frog mesenteric capillaries. J Physiol 503:413-425.

19. Knight AD, Levick JR. (1982). Pressure-volume relationships above and below atmospheric pressure in the synovial cavity of the rabbit knee. J Physiol 328:403420 .

20. Knight AD, Levick JR, McDonald JN. (1988). Relation between trans-synovial flow and plasma colloid osmotic pressure, with an estimation of the albumin reflection coefficient in the rabbit knee. QJ Exp Physiol 73:47-65.

21. Lampugnani MG, Resnati M, Dejana E, Marchisio PC. (1991). The role of integrins in the maintenance of endothelial monolayer integrity. J Cell Biol 112:479_ 490 .

22. Levick JR. (1980). Contributions of the lymphatic and microvascular systems to fluid absorption from the synovial cavity of the rabbit knee. J Physiol 306:455461.

23. Levick JR. (1994). An analysis of the interaction between extravascular plasma protein, interstitial flow and capillary filtration: application to synovium. $\mathrm{Mi}$ crovasc Res 47:90-125.

24. Levick JR, McDonald JN. (1989). Ultrastructure of transport pathways in stressed synovium of the knee in anaesthetized rabbits. J Physiol 419:493-508.

25. Levick JR, McDonald JN. (1994). Viscous and osmotically mediated changes of interstitial flow induced by extravascular albumin in synovium. Microvasc Res 47:68-89.

26. Levick JR, Michel CG. (1973). The permeability of individually perfused frog mesenteric capillaries to T1824 and T1824-albumin as evidence for a large pore system. Q J Exp Physiol 58:67-85.

27. Levick JR, Price FM, Mason RM. (1996). Synovial matrix-synovial fluid system of joints. In: Extracellular Matrix, Vol. II: Molecular Components \& Interactions. (WD Comper, Ed.). Amsterdam: Harwood Academic, 328-377.

28. Lin WL, Essner E. (1990). Immunogold localization of basement membrane molecules in rat retinal capillaries. Cell Mol Biol 36:13-21.

29. Linck G, Stocker S, Grimaud JA, Porte A. (1983). Distribution of immunoreactive fibronectin and collagen (type I, III, IV) in mouse joints. Histochemistry 77:323-328.

30. Lindblom A, Paulsson M. (1996). Basement membranes. In: Extracellular Matrix, Vol. II: Molecular Components \& Interactions. (WD Comper, Ed.). Amsterdam: Harwood Academic, 132-174.

31. Loftus JC, Liddington RC. (1997). New insights into integrin-ligand interaction. J Clin Invest 99:23022306.

32. Michel CG, Neal CR. (1999). Openings through endothelial cells associated with increased microvascular permeability. Microcirculation 6:45-54.

33. Nikkari L, Haapasalmi K, Aho H, Torvinen A, Sheppard D, Larjava H, Heino J. (1995). Localization of the alpha $\mathrm{v}$ subfamily of integrins and their putative ligands in synovial lining cell layer. J Rheumatol 22:16-23.

34. Park JH, Okavama N. Gute D, Krsmanovic A. Battarbee H, Alexander JS. (1999). Hypoxia/ aglycemia increases endothelial permeability: role of second messengers and cytoskeleton. Am J Physiol 277:C1066-C1074.

35. Pirilä L, Heino J. (1996). Altered integrin expression in rheumatoid synovial lining type-B cells - in vitro cytokine regulation of $\alpha 1 \beta 1, \alpha 6 \beta 1$ and $\alpha \mathrm{v} \beta 5$ integrins. J Rheumatol 23:1691-1698. 
36. Pirilä L, Aho H, Roivainen A, Konttinen YT, Pelliniemi LJ, Heino J. (2001). Identification of $\alpha_{6} \beta_{1}$ integrin positive cells in synovial lining layer as type B synoviocytes. J Rheumatol 28:478-483.

37. Poli A. Scott D, Bertin K, Miserocchi G, Mason RM. Levick JR. (2001). Influence of actin cytoskeleton on intra-articular and interstitial fluid pressure in synovial joints. Microvasc Res 62:293-305.

38. Poli A, Coleman PJ, Mason RM, Levick JR. (2002). Contribution of $\mathrm{F}$-actin to barrier properties of the blood-joint pathway. Microcirculation 9:419-430.

39. Price FM, Levick JR, Mason RM. (1996). Changes in glycosaminoglycan concentration and synovial permeability at raised intra-articular pressures in rabbit knees. J Physiol 495:821-833.

40. Qiao RL, Yan W, Lum H, Malik AB. (1995). Arg-GlyAsp peptide increases endothelial hydraulic conductivity; comparison with thrombin response. Am JPhysiol 269:C110-C117.

41. Reed RK, Woie K, Rubin K. (1997). Integrins and control of interstitial pressure. News Physiol Sci 12:4248.

42. Rinaldi N, Schwarz-Eywill M, Weiss D, LeppepmannJansen P, Lukoschek M, Keilholz U, Barth TF. (1997). Increased expression of integrins on fibroblast-like synoviocytes from rheumatoid arthritis in vitro correlates with enhanced binding to extracellular matrix proteins. Ann Rheum Dis 56:45-51.

43. Rinaldi N, Weiss D, Brado B, Schwarz-Eywill M, Lukoschek M, Pezzutto A, Keilholz U, Barth TF. (1997). Differential expression and functional behaviour of the alpha $\mathrm{v}$ and beta 3 integrin subunits in cytokine-stimulated fibroblast-like cells derived from synovial tissue of rheumatoid arthritis and osteoarthritis in vitro. Ann Rheum Dis 56:729-736.

44. Rippe B, Haraldsson B. (1994). Transport of macromolecules across microvascular walls: the two-pore theory. Physiol Rev 74:163-219.

45. Rubin K, Gullberg D, Tomasini-Johansson B, Reed RK, Ryden C, Borg TK. (1996). Molecular recognition of the extracellular matrix by cell surface receptors. In: Extracellular Matrix, Vol. II: Molecular Components \& Interactions (WD Comper, Ed.). Amsterdam: Harwood Academic, 262-309.

46. Ruoslahti E. (1996). RGD and other recognition sequences for integrins. Ann Rev Cell Dev Biol 12:697715.
47. Sabaratnam S, Coleman PJ, Badrick E, Mason RM, Levick JR. (2002). Interactive effect of chondroitin sulphate $\mathrm{C}$ and hyaluronan on fluid movement across rabbit synovium. J Physiol 540:271-284.

48. Schmidt C, Pommerenke H, Durr F, Nebe B, Rychly J. (1998). Mechanical stressing of integrin receptors induces enhanced tyrosine phosphorylation of cytoskeletally anchored proteins. J Biol Chem 273:5081-5085.

49. Scott D, Coleman PJ, Abiona A, Ashhurst DE, Mason RM, Levick JR. (1998). Effect of depletion of glycosaminoglycans and non-collagenous proteins on interstitial hydraulic permeability in rabbit synovium. J Physiol 511:629-643.

50. Shepard JM, Godorie SK, Brzyski N, Del Vecchio PJ, Malik AB, Kimelberg HK. (1987). Effects of alteration in endothelial cell volume on transendothelial albumin permeability. J Cell Physiol 133:389-394.

51. Sjaastad MD, Angres B, Lewis RS, Nelson WJ. (1994). Feedback regulation of cell-substratum adhesion by integrin-mediated intracellular $\mathrm{Ca}^{2+}$ signaling. Proc Natl Acad Sci USA 91:8214-8218.

52. Tak PP, Thurkow EW, Daha MR, Kluin PM, Smeets TJM, Meinders AE, Breeveld FC. (1995). Expression of adhesion molecules in early rheumatoid synovial tissue. Clin Immunol Immunopathol 77:236-242.

53. Wallis WJ, Simkin PA, Nelp WB. (1987). Protein traffic in human synovial effusions. Arthritis Rheum 30:57-63.

54. Walker A, Gallagher T. (1996). Structural domains of heparan sulphate for specific recognition of the C-terminal heparin-binding domain of human plasma fibronectin (HEPII). Biochem J 317:871-877.

55. Wolf J, Carsons S. (1991). Distribution of type VI collagen expression in synovial tissue and cultured synoviocytes : relation to fibronectin expression. Ann Rheum Dis 50:493-496.

56. Wu C, Hughes PE, Ginsberg MH, McDonald JA. (1996). Identification of a new biological function for the integrin alpha $\mathrm{v}$ beta 3 ; initiation of fibronectin matrix assembly. Cell Adhes Commun 4:149-158.

57. Wu MH, Ustinova E, Granger HJ. (2001). Integrin binding to fibronectin and vitronectin maintains the barrier function of isolated porcine coronary venules. J Physiol 532:785-791.

58. Zacharia ER, Lofthouse J, Flessner MF. (2000). Effect of intraperitoneal pressures on tissue water of the abdominal muscle. Am J Physiol 278:F875-F885. 